\title{
Synchronic nasopharyngeal and intraparotid warthin tumors: a case report and literature review
}

\author{
Karina-Lizbeth Yáñez-Barraza ${ }^{1}$, Hugo-Ricardo Domínguez-Malagon ${ }^{2}$, Adalberto Mosqueda-Taylor ${ }^{1}$, Ana- \\ María Cano-Valdez ${ }^{2}$, Kuauhyama Luna-Ortiz ${ }^{3}$ \\ ${ }^{1}$ Department of Health Care, Universidad Autónoma Metropolitana Xochimilco. Mexico City \\ ${ }^{2}$ Department of Surgical Pathology, Instituto Nacional de Cancerologia. Mexico City \\ ${ }^{3}$ Department of Head and Neck Surgery, Instituto Nacional de Cancerologia. México City
}

Correspondence:

Universidad Autònoma Metropolitana

Unidad Xochimilco

Calzada del Hueso 1100, Col. Villa Quietud,

Coyoacán, México, DF.

CP. 04960

México

karycdp@yahoo.com.mx

Yáñez-Barraza KL, Domínguez-Malagon HR, Mosqueda-Taylor A, CanoValdez AM, Luna-Ortiz K. Synchronic nasopharyngeal and intraparotid warthin tumors: a case report and literature review. J Clin Exp Dent. 2014;6(4):e435-9.

http://www.medicinaoral.com/odo/volumenes/v6i4/jcedv6i4p435.pdf

Received: 30/12/2013

Accepted: 01/05/2014

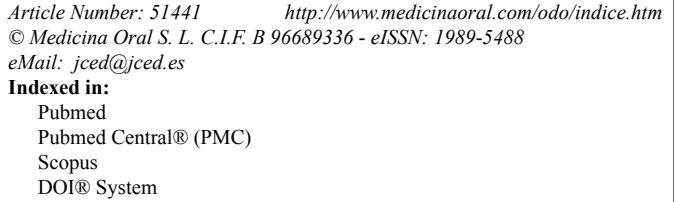

\begin{abstract}
Warthin tumor is the second most frequent benign salivary gland tumor after pleomorphic adenoma; it occurs almost exclusively in the parotid gland and peri-parotideal lymph nodes, although it may rarely present in other locations. It may be multicentric and bilateral in a small percentage of cases. Nasopharyngeal Warthin tumor is very rare, and the presence of a synchronic WT involving nasopharynx and parotid is an exceptional event, as it has been described only twice in the literature. In this article we report an additional case of a synchronic Warthin tumor and review the related literature.
\end{abstract}

Key words: Warthin tumor, synchronic WT, multicéntrico, nasopharynx.

\section{Introduction}

Warthin tumor (WT) was described for the first time in 1895 by Hildebrand as a variant of lateral cervical cyst (1) and 15 years later it received the name of Papillary Cystadenoma in a publication done by Albrecht and Arzt (2). In 1929 Warthin reported two similar cases and described the lesion as a slow-growing benign lymphoepithelial neoplasm, applying the name Lymphomatous Papillary Cistadenoma (3).

Warthin tumor is the second most frequent benign salivary gland tumor after pleomorphic adenoma; it occurs almost exclusively in the parotid gland and periparotideal lymph nodes, it may be multicentric in up to
$12-20 \%$, and bilateral in $5-14 \%$ of cases (4). Although extraparotideal WT is rare, isolated cases involving oral cavity (5), larynx (6) and cervical lymph nodes have been described (7). Nasopharyngeal WT is very rare, up to date only 5 cases in this location have been reported (8-12). However the presence of a synchronic WT involving nasopharynx and parotid is an exceptional event, and it has been described only twice in the literature $(13,14)$. Histogenesis of extraparotideal WT is controversial, several hypotheses have been proposed, the most accepted one suggests that it is due to delayed encapsulation of the parotid gland during the embryologic development, a theory that supposes some ducts and 
acini become trapped in extraparotideal lymph nodes giving rise to the tumor $(9,12,15)$. In the present article we report another case of a synchronic tumor and review the related literature.

\section{Case Report}

A 77 year-old man developed a slightly painful mass in the left side of the neck and weight lost of $2 \mathrm{~kg}$ over the last three months. In the past he worked in a recycling plant where he had direct contact with lead compounds for two months. The patient was a smoker for 49 years with a daily consumption of 18 cigarettes, and occasionally drank alcohol. Ten years before he had a myocardial infarct and was treated with antihypertensive drugs for the last five years (metoprolol). He is also being controlled for Diabetes Mellitus with oral drugs for the last 5 years. On physical examination a $6 \times 3 \mathrm{~cm}$ tumor was found in the left parotid gland. A nasal endoscopy disclosed a poorly delimited tumor in the Rosenmüller fossa measuring approximately $1 \times 1 \mathrm{~cm}$. Presence of these lesions was confirmed by computed tomography (Fig. 1). A superficial parotidectomy and biopsy of the nasopharyngeal lesion were performed.

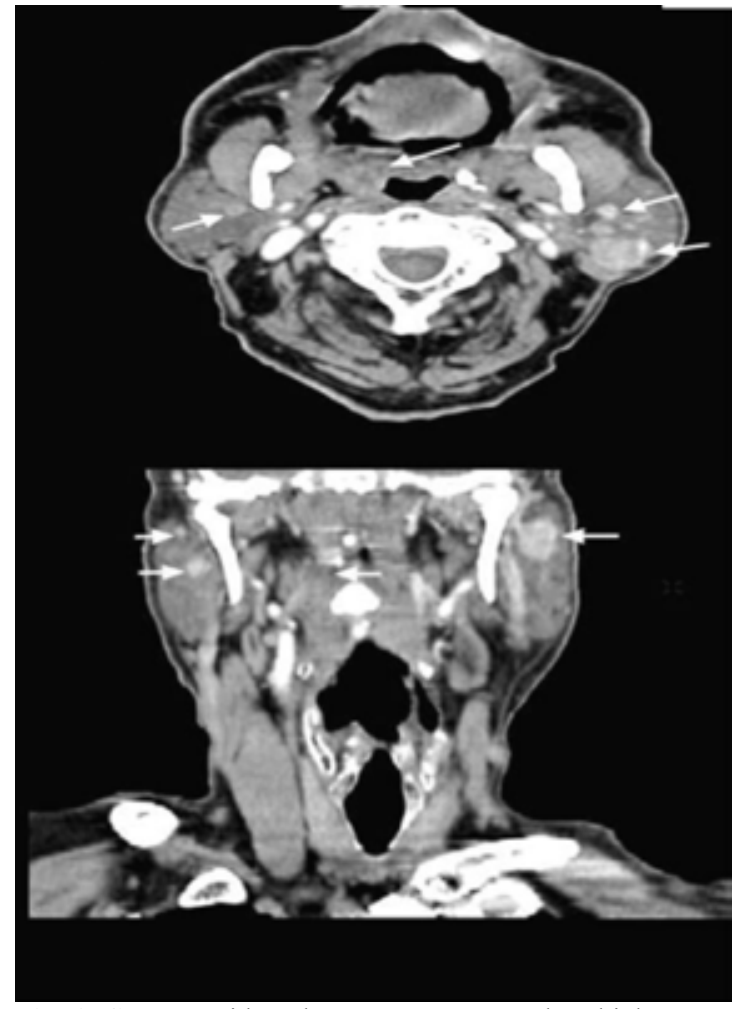

Fig. 1. CT scan with endovenous contrast and multiplanar reconstruction: Hyperdense lesions are seen in both parotid glands, two in each gland are identified, all lesion have well-defined borders, the largest one measures $27 \times 19 \mathrm{~mm}$. There is asymmetry of the Waldeyer's ring with increased volume and hyperdensity of the right side, and contralateral calcifications.

\section{Pathological Findings}

The nasopharyngeal tumor on gross inspection consisted of several fragments of bland, pale pink soft tissue measuring up to $3 \mathrm{~mm}$. Histologically it was characterized by papillary projections, and the surface was partially covered with ciliated epithelium. The papillae were lined by columnar cells with ample eosinophilic, granular cytoplasm, the nuclei were uniformly oval, with bland chromatin and inconspicuous nucleoli, and no mitotic activity was detected. The stalks of the papillae and adjacent connective tissue contained mature lymphoid tissue with a dense population of lymphocytes and plasma cells (Fig. 2).

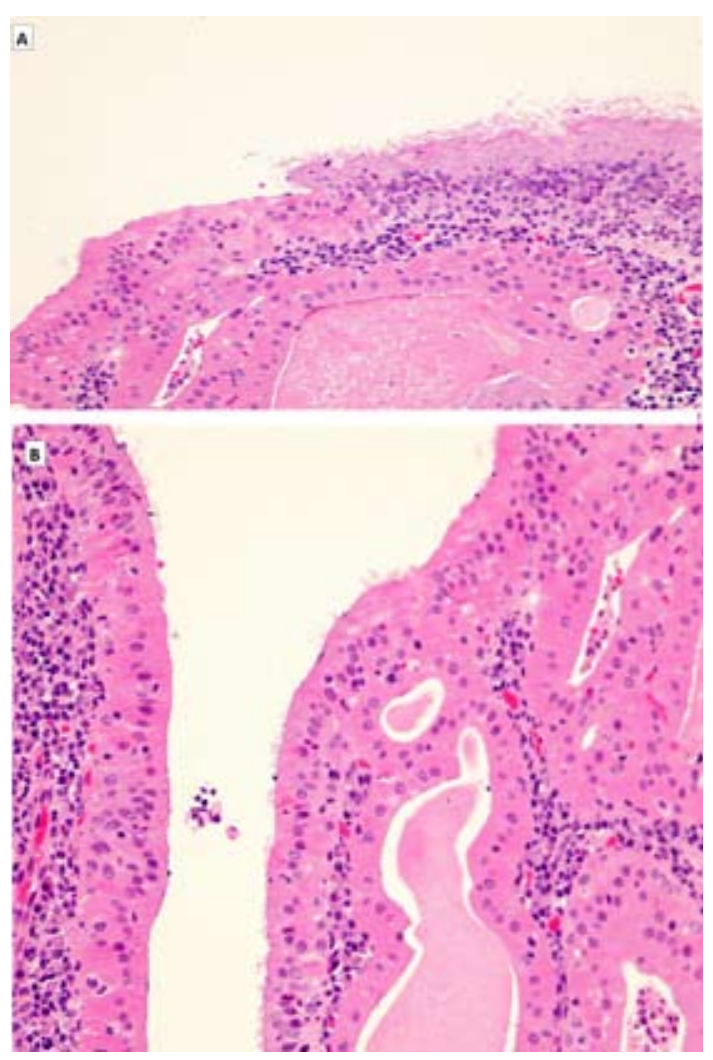

Fig. 2. (A) Low power view of nasopharyngeal tumor: Adenoid tissue with glandular and follicular structures lined by cubical cells with ample eosinophilic cytoplasm. Follicular lumens contains proteinaceous material. (B) High power view show on the surface ciliated epithelium partly replaced by cubical oncocytic cells with bland nuclei.

On gross examination, the superficial lobule of the parotid gland measured $7.5 \times 3.5 \times 2.5 \mathrm{~cm}$, showing on cut section two well circumscribed nodules, the largest measured $4 \times 2 \times 1.5 \mathrm{~cm}$. The cut surface had a granular appearance with dark brown areas alternating with light brown zones. Histologically both nodules were well delimited and showed cystic and papillary structures delineated by columnar cells with bland nuclei and abundant eosinophilic granular cytoplasm; the stoma displayed copious lymphoid tissue. The histological fea- 
tures were similar to the nasopharyngeal tumor (Fig. 3). Immunohistochemical studies were done to confirm the reactive nature of the lesion and showed: Epstein-Barr virus (LMP) was negative. Most of the lymphoid cells were B $(\mathrm{CD} 20+)$. CD3+ T cells constituted less $25 \%$ of the population with a CD4:CD8 ratio of $4: 1$. Five years after the surgical treatment the patient is asymptomatic, with no evidence of relapse.

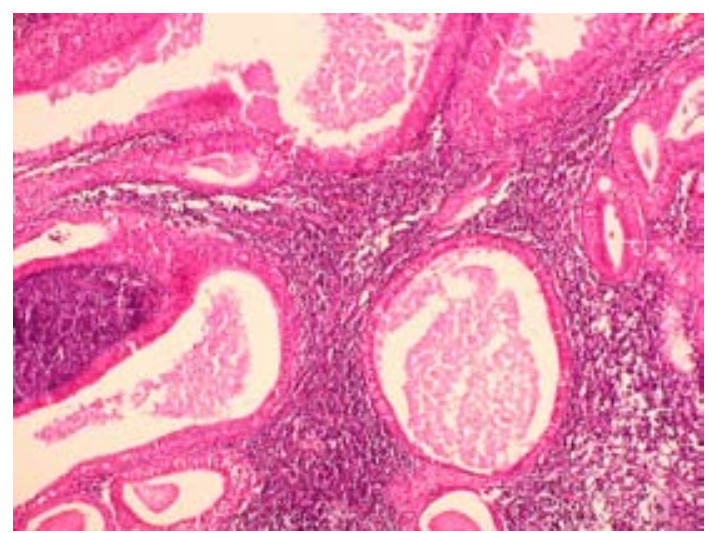

Fig. 3. Low power view of parotid tumor: Multiple cystic structures lined by cubical oncocytic cells. The supporting stroma shows lymphocytic infiltrate and formation of lymphoid follicles.

\section{Discussion}

Warthin tumor arises almost exclusively in the parotid gland, it frequently is associated to smoking, as the risk for developing it is 8 times higher in smokers than in non-smokers (15), our patient had a history of intense smoking for almost 50 years. Nasopharyngeal location of WT is a rare event, with only 5 cases informed to date (8-12). The synchronic presentation of WT in nasopharynx and parotid gland is exceptional. The first case was reported by Low et al. in 2002 (13), the patient was a 53 year-old Chinese woman with a $3 \mathrm{~cm}$ nodule in the right side of the neck behind the mandibular angle, and a naso-endoscopy showed a $1 \mathrm{~cm}$ nodule located in the postnasal space. The histological examination rendered the diagnosis of WT in both locations. Hilton et al. reported in 2008 the case of a 55 year-old man with multifocal WT that affected both parotid glands, postnasal space, base of the tongue and tonsils (14).

Based on the literature review (Table 1), nasopharyngeal WT has a predilection for old individuals, with a mean age of 69.5 years (range 53-81 years), and there have been 5 male and 3 female patients. Heavy smoking was reported in three patients and is not mentioned in the remaining five. Most tumors were small, four measured less than $1 \mathrm{~cm}$, three were 2 to $3 \mathrm{~cm}$ in diameter, and size was not mentioned in one. Symptoms were related to their nasopharyngeal location near the Eustachian tube, and included: otalgia, cough, dizziness, hypoacusia, and nasopharyngeal discomfort. The time to diagnosis was 3 to 24 months with a mean of 14 months.

Histogenesis of extraparotideal WT has been widely debated and actually is controversial. Several hypotheses have been proposed, the most accepted one suggests that it is due to delayed encapsulation of the parotid gland during the embryologic development, a theory that supposes some ducts and acini become trapped in extraparotideal lymph nodes giving rise to the tumor $(9,12,15)$. Regarding the lymphoid component, some authors consider it as a pre-existing lymph node trapped in the gland, and the lymphoid response represents an exaggerated immune response (9). According to the so-called heterotopic theory it is possible that during the embryonic development, epithelial cells from the second, third and fourth pharyngeal pouches that normally descend to the mediastinum become trapped in lymphoid organs; this could explain the extraparotideal location of WT (16). However, the epithelium of the pharyngeal pouches is dissimilar to the epithelial component of WT. According with this theory Seifert et al. (17), classified WTs into different subtypes based mainly on their lymphoid component, these authors proposed a staged pathogenic development in which subtype III (lymphoid predominance) WT constitutes an initial stage from which the subtype-I (typical) and subtype II (Epithelial predominance) WTs subsequently evolve. However, the amount of lymphoid tissue often exceeds that of the small lymph node from which it supposedly originates (16).

Other hypothesis postulate that in pharyngeal WT the lymphoid cells are reactive, polyclonal, and have a Bcell predominance, this chronic inflammation would induce oncocytic metaplasia of salivary epithelium trapped in lymphoid tissue (9). Other authors suggest that the lymphoid component of nasopharyngeal WT could represent an immune response $(11,16)$. Some authors propose that virus infect ductal epithelial cells, and the release of gene products or cytokines by infected cells may activate lymphoid tissue and result in a polyclonal $\mathrm{B} /$ cell response (18-20). On this regard, some authors have suggested as a cause chronic obstruction of the nasopharinx (8) and intense smoking as an irritating factor $(10,14)$, the lymphoid population in our case was polyclonal with $\mathrm{B}$ cell predominance indicating a reactive phenomenon as suggested by Yeh et al. (9).

Although the presence of synchronic tumors in the same patient may be coincidental, it is important to try to establish a link between them. WT can occur synchronously with other neoplasias such as pleomorphic adenoma Seifert et al. (21) and Low et al. suggested that in their case the parotid WT could be metastasis from the nasopharyngeal WT, a dubious explanation because both tumors were histologically benign (13). However, some tumors with bland histology, such as ameloblastoma and pleomorphic adenoma, may produce metastasis 
Table 1. Nasopharyngeal Warthin Tumors reported in the literature.

\begin{tabular}{|c|c|c|c|c|c|c|c|c|}
\hline Case & $\begin{array}{l}\text { Years } \\
\text { old }\end{array}$ & Sex & Location & Size of the tumor & Smoking & $\begin{array}{l}\text { Systemic or } \\
\text { locals diseases }\end{array}$ & $\begin{array}{l}\text { Time at the } \\
\text { moment of } \\
\text { the Diagnosis }\end{array}$ & Symptoms \\
\hline 1. (8) & $74 y$ & Female & $\begin{array}{l}\text { Nasopharingeal } \\
\text { mucosa }\end{array}$ & $10 \times 5 \times 3 \mathrm{~mm}$ & -- & $\begin{array}{l}\text { Bilateral obs- } \\
\text { tructing nasal } \\
\text { polyposis, } \\
\text { otitis media }\end{array}$ & 12 months & $\begin{array}{l}\text { One year right- } \\
\text { sided hearing } \\
\text { loss }\end{array}$ \\
\hline 2. (11) & $81 \mathrm{y}$ & Female & $\begin{array}{l}\text { Left Eustachian } \\
\text { tube }\end{array}$ & $0.5 \times 1.0 \times 0.9 \mathrm{~mm}$ & -- & -- & --- & $\begin{array}{l}\text { Left sided } \\
\text { otalgia and con- } \\
\text { ductive hearing } \\
\text { loss. }\end{array}$ \\
\hline 3. (9) & $71 \mathrm{y}$ & Male & $\begin{array}{l}\text { Right posterior } \\
\text { nasopharynx }\end{array}$ & $0.4 \mathrm{~cm}$ diameter & -- & $\begin{array}{l}\text { Hypertension, } \\
\text { gout, chronic } \\
\text { obstructive } \\
\text { pulmonary di- } \\
\text { sease, kidney } \\
\text { failure }\end{array}$ & 12 months & $\begin{array}{l}\text { Chilliness, } \\
\text { cough, fever, } \\
\text { dizziness. }\end{array}$ \\
\hline 4. (10) & $69 \mathrm{y}$ & Male & $\begin{array}{l}\text { Right Eustachian } \\
\text { tube }\end{array}$ & $22 \mathrm{~mm}$ diameter & $\begin{array}{l}20 \text { ciga- } \\
\text { rettes per } \\
\text { day for } \\
45 \text { years }\end{array}$ & $\begin{array}{l}\text { History of } \\
\text { miringoplasty } \\
\text { right ear } 10 \\
\text { years before. }\end{array}$ & 4 months & $\begin{array}{l}\text { Epixtasis, right } \\
\text { hipoacusia }\end{array}$ \\
\hline $5 .(12)$ & $76 y$ & Male & $\begin{array}{l}\text { Right side of the } \\
\text { posterior na- } \\
\text { sopharynx exten- } \\
\text { ding to the soft } \\
\text { palate. }\end{array}$ & -- & -- & $\begin{array}{l}\text { Gastric cancer } \\
8 \text { years before. }\end{array}$ & 16 months & $\begin{array}{l}\text { Unilateral } \\
\text { nasopharyngeal } \\
\text { discomfort. }\end{array}$ \\
\hline $6 .(13)$ & $53 \mathrm{y}$ & Female & $\begin{array}{l}\text { - Parotid } \\
\text { - Righ side of the } \\
\text { postnasal space. }\end{array}$ & $\begin{array}{l}3.0 \times 1.5 \mathrm{~cm} \\
1.0 \text { diameter }\end{array}$ & -- & --- & 24 months & $\begin{array}{l}\text { Right upper } \\
\text { neck mass. }\end{array}$ \\
\hline 7. (14) & $55 \mathrm{y}$ & Male & $\begin{array}{l}\text { - Bilateral parotid } \\
\text { glands. } \\
\text { - Post/nasal space } \\
\text { - Base of tongue } \\
\text { - Tonsilar areas }\end{array}$ & $\begin{array}{l}\text { - Parotid } \\
\text { glands: } 1.5 \text { and } \\
2 \mathrm{~cm} \text { diameter } \\
\text { respectively } \\
\text { - Post/nasal space, } \\
\text { base of tongue and } \\
\text { tonsilar areas: } 3 \times 3 \\
\mathrm{~cm} \text {. }\end{array}$ & $\begin{array}{l}10 \text { ciga- } \\
\text { rrettes } \\
\text { per day } \\
\text { for many } \\
\text { years. }\end{array}$ & --- & $\begin{array}{l}\text { - Parotid } \\
\text { glands: } \\
\text { many years. } \\
\text { - Other sites: } \\
\text { Six years. }\end{array}$ & $\begin{array}{l}\text {-Parotid glands: } \\
\text { slowly increa- } \\
\text { sing. } \\
\text { - Other sites: } \\
\text { Painless neck } \\
\text { mass at the } \\
\text { angle of the left } \\
\text { mandible. }\end{array}$ \\
\hline 8. * & $77 \mathrm{y}$ & Male & $\begin{array}{l}\text { - Left Parotid gland } \\
\text { - Rosen muller fossa }\end{array}$ & $\begin{array}{l}3 \times 6 \mathrm{~cm} \\
1 \times 1 \mathrm{~cm}\end{array}$ & $\begin{array}{l}18 \text { ciga- } \\
\text { rettes per } \\
\text { day for } \\
49 \text { years }\end{array}$ & $\begin{array}{l}10 \text { years } \\
\text { before he had } \\
\text { myocardial in- } \\
\text { farct, Diabetes } \\
\text { Mellitus. }\end{array}$ & 3 months & $\begin{array}{l}\text { Painful mass } \\
\text { in the left side } \\
\text { of the neck, } \\
\text { weight lost. } \\
\text { Dysphonia. }\end{array}$ \\
\hline
\end{tabular}

* Present case.

after many recurrences, which can still preserve benign histomorphological features $(22,23)$.

Other authors postulate that multiple systemic factors such as nutritional or metabolic deficiencies, genetic factors, environmental influences, duct obstruction or chronic inflammation may concur to generate oncocytic metaplasia that could be the initial stage of a synchronous development of WT (11). Yeh et al. believes that the chronic inflammation in the nasopharynx induces the formation of oncocytic metaplasia of the glandular tissues in the stroma (9).
In conclusion, simultaneous WT in the nasopharynx and parotid gland has been reported only twice before, and although this occurrence may be coincidental, a common pathogenesis or a metastatic mechanism have to be considered. Even though the number of cases of extraparotideal WT is small, further investigation is required to establish if there are clinical, demographic and pathological differences among patients with intraparotideal, extraparotideal and synchronic WT. 


\section{References}

1. Hildebrand $\mathrm{O}$. Uber angerborene epitheliale cysten und fisten des halses. Arch Klin Chir. 1895;49:167-206.

2. Albrecht $D$, Arzt L. Beitrage zur frague der gewebsverrung.papillare cystadenoma in lymphdrusen. Frankfurt Z Pathol. 1910;4:47-69.

3. Warthin AS. Papillary cystadenoma lymphomatosum. A rare teratoid of the parotid region. J Cancer Res. 1929;13:116-25.

4. Maiorano L, Lo ML, Favia G, Piattelli A. Warthin's Tumour : a study of 78 cases with emphasis on bilaterality, multifocality and association with other malignancies. Oral Oncol 2002;38:35-40.

5. Hart MN, Andrews JL. Papillary cystadenoma lymphomatosum arising in the cavity oral. Oral Surg. 1968;26:588-91.

6. Foulsham CK, Synder GG, Carpenter RJ. Papillary cystadenoma lymphomatosum of the larynx. Otolaryngol Head Neck Surg. 1981;89:960-4.

7. Fantozzi RD, Bone RC, Fox R. Extraglandular Warthin's tumor. Laryngoscope. 1985;95:682-8.

8. Kristensen S, Tveteras K, Friedmann I, Thomsen P. Nasopharyngeal Warthin's tumour: A metaplastic lesion. J Laryngol Otol. 1989;103:616-9.

9. Yeh YA, Baker LL, Wang John, Fan K, Nasopharyngeal Warthin's tumor. Otolaryngol Head and Neck Surg. 1999;120:942-4.

10. Berrocal P, Galera R, Ruiz C, González GJ, Muñoz BF. Tumor de Warthin ectópico en la nasofaringe. A propósito de un caso clínico. Acta Otorrinolaringol Esp. 2005;56:328-30.

11. Griffiths AP, Dekker P. Oncocytic metaplasia of the nasopharynx or extra-parotid Warthin's tumour? J Clin Pathol. 1991;44:1030-2.

12. Michiro K, Kanako I, Hitoshi T, Sawako H. Warthin's tumor of the nasopharyx: a case report. Auris Nasus Larynx. 2004;31:293-8.

13. Low WK, Bian S. Synchronous parotid and nasopharyngeal Warthin's Tumors: First report of a case. ENT-ear, Nose and Throat Journal. 2002;81:839-41.

14. Hilton JM, Phillips JS, Hellquist HB, Premachandra DJ. Multifocal multi-site Warthin tumour. Eur Arch Otorhinolaryngol. 2008;265:1573-5.
15. Mao-Che W, Tung LS, Paul CHC, Chia YL, Pen YC. Extraparotid Warthin's tumor presented as a Neck mass. J Chin Med Assoc. 2003;66:752-4.

16. Aguirre JM, Echebarría MA, Martínez CR, Rodríguez C, Burgos JJ, Rivera M. A new Hypothesis concerning its developmental. Oral Surg Oral Med Oral Pathol Oral radiol Endod. 1998;85:60-3.

17. Seifert G, Bull HG, Donath K. Histologic subclassification of the cystadenolymphoma of the parotid gland: analisys of 275 cases. Virchows Arch (Pathol Anat). 1980;388:13-38.

18. Gallo O. New insights into the pathogenesis of Warthin's tumour. Oral Oncol Eur J Cancer. 1995;31B:211-5.

19. Scully C. Viruses and salivary gland disease: are there associations? Oral Surg Oral Med Oral Pathol Oral radiol Endod. 1988;66: 179-83.

20. Santucci M, Gallo O, Calzolari A, Bondi R. Detection of Epstein Barr viral genome in tumor cells of Warthin's tumour of parotid gland. Am J Clin Pathol. 1993;100:662-5.

21. Seifert G, Donath K. Multiple tumours of the salivary glands- terminology and nomenclature. Eur J Cancer B Oral Oncol. 1996:32B: 251-9.

22. Artés MJ, Prieto RM, Navarro HM, Peñas PL, Camañas SA, Vaquero de la Hermosa MC, Vera S F. Ameloblastoma. Diagnosis by means of FNAB. Report of two cases. Med Oral Patol Oral Cir Bucal. 2005; 10:205-9.

23. Chen I, Tu H, Pleomorphic adenoma to the parotid gland metastasizing to the cervical lymph node. Otolaryngol Head Neck Surg. 2000;122:455-7.

\section{Conflict of Interest}

The authors declare that they have no conflict of interest. 